\title{
Water solubility in aluminosilicate melts of haplogranite composition at $2 \mathrm{kbar}$
}

\author{
François Holtz ${ }^{\mathrm{a}, \alpha}$, Harald Behrens ${ }^{\mathrm{a}}$, Donald B. Dingwell ${ }^{\mathrm{b}}$ and Richard P. Taylor ${ }^{\mathrm{c}}$ \\ ${ }^{a}$ Institut für Mineralogie, Universität Hannover, Welfengarten 1, 3000 Hannover 1, Federal Republic of Germany \\ ${ }^{\mathrm{b}}$ Baverisches Geoinstitut, Universität Bayreuth, Postfach 101 251, 8580 Bayreuth, Federal Republic of Germany \\ ${ }^{c}$ Department of Earth Sciences, Carleton University, Ottawa, Ont. K1S 5B6, Canada
}

(Accepted for publication December 4, 1991)

\begin{abstract}
Holtz, F., Behrens, H., Dingwell, D.B. and Taylor, R.P., 1992. Water solubility in aluminosilicate melts of haplogranite composition at 2 kbar. In: Y. Bottinga, D.B. Dingwell and P. Richet (Guest-Editors), Silicate Melts. Chem. Geol., 96: 289-302.

The compositional dependence of $\mathrm{H}_{2} \mathrm{O}$ solubility was investigated at $2 \mathrm{kbar}$ and $800^{\circ} \mathrm{C}$ in haplogranite melts (system $\mathrm{SiO}_{2}-\mathrm{NaAlSi}_{3} \mathrm{O}_{8}-\mathrm{KAlSi}_{3} \mathrm{O}_{8}$ or $\left.\mathrm{Qz}-\mathrm{Ab}-\mathrm{Or}\right)$. The sixteen investigated compositions contained 25,35 or 45 wt. $\%$ normative $\mathrm{Qz}$ and various $\mathrm{Ab} /(\mathrm{Ab}+\mathrm{Or})$ ratios (0.15-0.92). Starting solid materials were anhydrous bubble-free glasses to which 10 wt. $\% \mathrm{H}_{2} \mathrm{O}$ was added. The $\mathrm{H}_{2} \mathrm{O}$ contents of the isobarically quenched melts (glasses) were measured by Karl-Fischer titration.

The results show that $\mathrm{H}_{2} \mathrm{O}$ solubility in aluminosilicate melts depends significantly upon anhydrous composition. The highest solubility values are obtained for the most Ab-rich melts. At a constant normative quartz content, the solubility of water decreases from $6.49 \pm 0.20 \mathrm{wt} . \% \mathrm{H}_{2} \mathrm{O}$ for a composition $\mathrm{Qz}_{35} \mathrm{Ab}_{60} \mathrm{Or}_{05}$ (normative composition expressed in wt.\%) to $5.50 \pm 0.15 \mathrm{wt} \% \mathrm{H}_{2} \mathrm{O}$ for a composition $\mathrm{Qz}_{35} \mathrm{Ab}_{10} \mathrm{Or}_{55}$. Along this join, the most significant changes are observed for Ab-rich melts whereas $\mathrm{H}_{2} \mathrm{O}$ solubility in $\mathrm{Or}$-rich melts remains almost constant.

The $\mathrm{H}_{2} \mathrm{O}$ solubility data imply that $\mathrm{H}_{2} \mathrm{O}$ is preferentially associated with the $\mathrm{Ab}$ component in aluminosilicate melts. Application of the results to natural granitic melts suggests that $\mathrm{Na}$-rich, $\mathrm{H}_{2} \mathrm{O}$-saturated melts may be significantly less viscous than $\mathrm{H}_{2} \mathrm{O}$-saturated, K-rich melts.

The temperature dependence of $\mathrm{H}_{2} \mathrm{O}$ solubility, investigated for composition $\mathrm{Qz}_{28} \mathrm{Ab}_{38} \mathrm{Or}_{34}$ at $2 \mathrm{kbar}$, is low. Increasing temperature from $750^{\circ}$ to $1150^{\circ} \mathrm{C}$ only causes a decrease in $\mathrm{H}_{2} \mathrm{O}$ solubility from 6.00 to 5.41 wt. $\% \mathrm{H}_{2} \mathrm{O}$. These data are in agreement with previous data obtained for albite melts.
\end{abstract}

\section{Introduction}

The solubility of $\mathrm{H}_{2} \mathrm{O}$ in natural or synthetic granitic melts has been the subject of numerous studies (e.g., Goranson, 1931; Khitarov et al., 1959; Burnham and Jahns, 1962; Orlova, 1963; Oxtoby and Hamilton, 1978a, b; Dingwell et al., 1984). However, there are significant variations in the data for a given pressure $(P)$, temperature $(T)$ and composition. As a

\footnotetext{
${ }^{\alpha}$ Present address: CRSCM-CNRS, 1A rue de la Férol-
} lerie, F-45071 Orléans, France. typical example, the reported $\mathrm{H}_{2} \mathrm{O}$ solubility in albite melts varies from 7 to $10 \mathrm{wt} . \%$ at $3 \mathrm{kbar}$ (e.g., Goranson, 1931; Burnham and Jahns, 1962; Orlova, 1963; Oxtoby and Hamilton, 1978a; Dingwell, 1987; Blamart et al., 1988). The variation of the data is due to the use of various starting materials (gel, powdered glass, pieces of glass, crystals ) and various analytical techniques for the determination of the $\mathrm{H}_{2} \mathrm{O}$ content (see reviews in Day and Fenn, 1982; Dingwell et al., 1984; McMillan and Holloway, 1987). In addition, quenching may not have been always performed under perfectly 
isobaric conditions, a factor which may influence significantly the solubility data. Thus, data obtained by different methods are not directly comparable and the absolute value of $\mathrm{H}_{2} \mathrm{O}$ solubility is only known within a large uncertainty.

This study is an attempt to determine the effect of melt composition on the solubility of $\mathrm{H}_{2} \mathrm{O}$ in the system $\mathrm{SiO}_{2}(\mathrm{Qz})-\mathrm{NaAl}-$ $\mathrm{Si}_{3} \mathrm{O}_{8}(\mathrm{Ab})-\mathrm{KAlSi}_{3} \mathrm{O}_{8}(\mathrm{Or})$ by using a single experimental and analytical method to obtain a consistent dataset at constant $P$ and $T$ ( 2 kbar, $800^{\circ} \mathrm{C}$ ). In order to extend the compositional dependence to other temperatures, the effect of $T$ on $\mathrm{H}_{2} \mathrm{O}$ solubility has also been investigated for one composition close to the minimum melt composition (composition with the lowest liquidus temperature in the $\mathrm{Qz}-$ $\mathrm{Ab}-\mathrm{Or}$ system or composition of the liquid participating in the solidus reactions ). Most of the previous investigations of $\mathrm{H}_{2} \mathrm{O}$ solubility in the system $\mathrm{Qz}-\mathrm{Ab}-\mathrm{Or}$ were carried out with one or with a limited number of compositions (mainly pure albite melts). One exception is the work of Voigt et al. (1981) in which $\mathrm{H}_{2} \mathrm{O}$ solubility was investigated for several compositions in the binary system $\mathrm{Ab}-\mathrm{Or}$ (however, data are only given for the $\mathrm{Ab}$ and Or endmember compositions ). Clearly, there is a need for a coherent dataset of $\mathrm{H}_{2} \mathrm{O}$ solubility values for compositions in the system $\mathrm{Qz}-\mathrm{Ab}-\mathrm{Or}$, considering the important contribution of this system (e.g., Tuttle and Bowen, 1958) to the interpretation of granites and rhyolites. Although $\mathrm{H}_{2} \mathrm{O}$ solubility has been measured for a variety of natural granitic and rhyolitic rocks (e.g., Khitarov et al., 1959; Burnham and Jahns, 1962; Oxtoby and Hamilton, 1978a) such data cannot be easily interpreted because they were obtained for a single multicomponent composition, in which additional elements, although present only in low concentrations may still influence significantly the solubility data (i.e. F, B, Li, Rb, excess Al). In addition, considering the current debate on solubility mechanisms of $\mathrm{H}_{2} \mathrm{O}$ in aluminosilicate melts (e.g., Burnham, 1981; Stolper, 1982;
Mysen and Virgo, 1986; Kohn et al., 1989; Silver and Stolper, 1989; Silver et al., 1990), an internally consistent $\mathrm{H}_{2} \mathrm{O}$ solubility dataset in the system $\mathrm{Qz}-\mathrm{Ab}-\mathrm{Or}$ may help to provide new insight into the solution mechanism ( $s$ ) of $\mathrm{H}_{2} \mathrm{O}$ in such systems.

\section{Starting material and experimental technique}

\subsection{Starting glasses}

The starting materials for preparation of the haplogranite glasses were powders of $\mathrm{Na}_{2} \mathrm{CO}_{3}$, $\mathrm{K}_{2} \mathrm{CO}_{3}, \mathrm{Al}_{2} \mathrm{O}_{3}$ and $\mathrm{SiO}_{2}$ of p.a. quality. Sixteen compositions with three different normative $\mathrm{Qz}$ contents were synthesized $\left(\mathrm{Qz}_{45}, \mathrm{Qz}_{35}\right.$, $\mathrm{Qz}_{25}$ ). Along these sections at constant normative $\mathrm{Qz}$ content, five or six compositions with different $A b /(A b+O r)$ ratios were prepared. The powders of the starting materials were dried at $120^{\circ} \mathrm{C}$ overnight prior to weighing. The powders were mixed in plastic bottles by agitation for $\sim 5-10 \mathrm{~min}$. The mixtures were melted stepwise into $75 \mathrm{~cm}^{3}$ thin-walled platinum crucibles and fused directly at $1600^{\circ} \mathrm{C}$ over a period of several hours. The products of the initial fusions were bubble-rich and inhomogeneous. To remove the bubbles and promote homogenization, the fused batches were loaded into a box furnace and reheated at $1700^{\circ} \mathrm{C}$. At this temperature, the melts were stirred at $10-20 \mathrm{rpm}$ with a $\mathrm{Pt}_{80} \mathrm{Rh}_{20}$ spindle for several days until virtually devoid of bubbles. The bubble content of the liquids was periodically checked by removing the stirrer from the melt and inspecting optically the adhered melt. Bubble-free melts were cooled slowly in the box furnace to $<800^{\circ} \mathrm{C}$, and then removed with their mullite cradles and allowed to cool slowly to room temperature in order to prevent excessive cracking during quenching.

The glass used for the investigation of $T$ dependence was prepared by Schott Company (Mainz, Germany; melting number N8886) 
and contained few bubbles.

The homogeneity and composition of the starting glasses were tested by electron microprobe analysis. The results of the analyses are given in Table 1 as the proportions of the oxides and as recalculated CIPW normative contents of quartz $(\mathrm{Qz})$, albite $(\mathrm{Ab})$ and orthoclase (Or). The compositions are also plotted in the $\mathrm{Qz}-\mathrm{Ab}-\mathrm{Or}$ ternary diagram in Figs. 1 and 2 (open circles for glasses prepared by ourselves, star for the glass prepared by Schott ${ }^{\circledR}$ ).

\subsection{Experimental procedure and apparatus}

The same procedure was used for all experiments carried out in order to define the compositional dependence of $\mathrm{H}_{2} \mathrm{O}$ solubility (experiments at $800^{\circ} \mathrm{C}$ ). Small glass cylinders (diameter: $3 \mathrm{~mm}$; length: $2-3 \mathrm{~mm}$ ) were sampled by diamond coring tools, cleaned ultrasonically in acetone and then dried at $110^{\circ} \mathrm{C}$ to remove any residue of acetone. In each gold capsule (diameter: $4 \mathrm{~mm}$; length: $15 \mathrm{~mm}$ ), one cylinder was sealed together with $\sim 10 \mathrm{wt} . \%$ of

\section{TABLE 1}

Composition of starting glasses (average values of 10 microprobe analyses, compositions normalized to $100 \%$ )

\begin{tabular}{|c|c|c|c|c|c|c|c|c|}
\hline $\begin{array}{l}\text { No. } \\
\mathrm{Qz} / \mathrm{Ab} / \mathrm{Or}\end{array}$ & $\begin{array}{l}\text { HPG } 1 \\
25 / 60 / 15\end{array}$ & $\begin{array}{l}\text { HBG2 } \\
25 / 50 / 25\end{array}$ & $\begin{array}{l}\text { HBG3 } \\
25 / 40 / 35\end{array}$ & $\begin{array}{l}\text { HPG4 } \\
25 / 30 / 45\end{array}$ & $\begin{array}{l}\text { HPG5 } \\
25 / 20 / 55\end{array}$ & $\begin{array}{l}\text { HPG6 } \\
35 / 60 / 05\end{array}$ & $\begin{array}{l}\text { HPG } 7 \\
35 / 50 / 15\end{array}$ & $\begin{array}{l}\text { HPG } 8 \\
35 / 40 / 25\end{array}$ \\
\hline \multicolumn{9}{|c|}{ Composition of major oxides (wt.\%): } \\
\hline $\mathrm{K}_{2} \mathrm{O}$ & 2.55 & 4.24 & 5.92 & 7.48 & 9.25 & 0.89 & 2.61 & 4.23 \\
\hline $\mathrm{Na}_{2} \mathrm{O}$ & 6.71 & 5.74 & 4.63 & 3.50 & 2.38 & 6.48 & 5.67 & 4.60 \\
\hline $\mathrm{Al}_{2} \mathrm{O}_{3}$ & 14.11 & 13.94 & 13.95 & 13.70 & 13.55 & 12.43 & 12.25 & 12.07 \\
\hline $\mathrm{SiO}_{2}$ & 76.63 & 76.08 & 75.50 & 75.32 & 74.82 & 80.19 & 79.47 & 79.10 \\
\hline \multicolumn{9}{|c|}{ CIPW norms: } \\
\hline $\mathrm{Qz}$ & 27.85 & 26.75 & 26.14 & 26.86 & 26.70 & 39.10 & 36.51 & 36.38 \\
\hline Or & 15.07 & 25.00 & 34.93 & 44.30 & 54.61 & 5.26 & 15.42 & 25.00 \\
\hline $\mathrm{Ab}$ & 56.70 & 48.15 & 38.85 & 28.78 & 18.25 & 54.83 & 74.97 & 38.53 \\
\hline C & 0.38 & - & - & - & - & 0.81 & 0.10 & - \\
\hline $\mathrm{KS}$ & - & - & - & - & - & - & - & - \\
\hline $\mathrm{NaS}$ & - & 0.10 & 0.08 & 0.21 & 0.44 & - & - & 0.09 \\
\hline
\end{tabular}

\begin{tabular}{|c|c|c|c|c|c|c|c|c|c|}
\hline $\begin{array}{l}\text { No. } \\
\text { Qz/Ab/Or }\end{array}$ & $\begin{array}{l}\text { HPG9 } \\
35 / 30 / 35\end{array}$ & $\begin{array}{l}\text { HPG } 10 \\
35 / 20 / 45\end{array}$ & $\begin{array}{l}\text { HPG } 11 \\
35 / 10 / 55\end{array}$ & $\begin{array}{l}\text { HPG } 12 \\
45 / 50 / 05\end{array}$ & $\begin{array}{l}\text { HPG } 13 \\
45 / 40 / 15\end{array}$ & $\begin{array}{l}\text { HPG } 14 \\
45 / 30 / 25\end{array}$ & $\begin{array}{l}\text { HPG } 15 \\
45 / 20 / 35\end{array}$ & $\begin{array}{l}\text { HPG /6 } \\
45 / 10 / 45\end{array}$ & $\begin{array}{l}\text { Schott } \\
28 / 38 / 34\end{array}$ \\
\hline \multicolumn{10}{|c|}{ Composition of major oxides (wt.\%): } \\
\hline $\mathrm{K}_{2} \mathrm{O}$ & 5.89 & 7.50 & 9.24 & 0.89 & 2.64 & 4.21 & 5.90 & 7.64 & 5.68 \\
\hline $\mathrm{Na}_{2} \mathrm{O}$ & 3.46 & 2.38 & 1.21 & 5.46 & 4.54 & 3.48 & 2.37 & 1.21 & 4.65 \\
\hline $\mathrm{Al}_{2} \mathrm{O}_{3}$ & 11.83 & 11.85 & 11.79 & 10.59 & 10.45 & 10.24 & 10.09 & 10.13 & 13.53 \\
\hline $\mathrm{SiO}_{2}$ & 78.82 & 78.27 & 77.76 & 83.06 & 82.37 & 82.06 & 81.64 & 81.03 & 76.14 \\
\hline \multicolumn{10}{|l|}{ CIPW norm: } \\
\hline Qz & 36.86 & 36.27 & 35.96 & 47.90 & 45.86 & 45.84 & 45.85 & 45.13 & 28.16 \\
\hline Or & 34.80 & 44.32 & 54.60 & 5.26 & 15.60 & 24.88 & 34.86 & 45.14 & 33.59 \\
\hline $\mathrm{Ab}$ & 28.06 & 19.20 & 9.20 & 46.20 & 38.41 & 29.23 & 19.05 & 9.57 & 37.92 \\
\hline $\mathrm{C}$ & - & - & - & 0.64 & 0.12 & - & - & - & - \\
\hline KS & - & - & - & - & - & - & - & - & - \\
\hline $\mathrm{NaS}$ & 0.28 & 0.22 & 0.24 & - & - & 0.05 & 0.23 & 0.16 & 0.33 \\
\hline
\end{tabular}

Glasses labelled HPG were synthesized by ourselves. Glass labelled Schott ${ }^{\circledR}$ was synthesized by Schott Company, Mainz, Germany. $\mathrm{Qz}=$ quartz; $\mathrm{Or}=$ orthoclase; $\mathrm{Ab}=$ albite $\mathrm{C}=$ corundum; $\mathrm{NaS}=\mathrm{Na}_{2} \mathrm{SiO}_{3} ; \mathrm{KS}=\mathrm{K}_{2} \mathrm{SiO}_{3}$. 


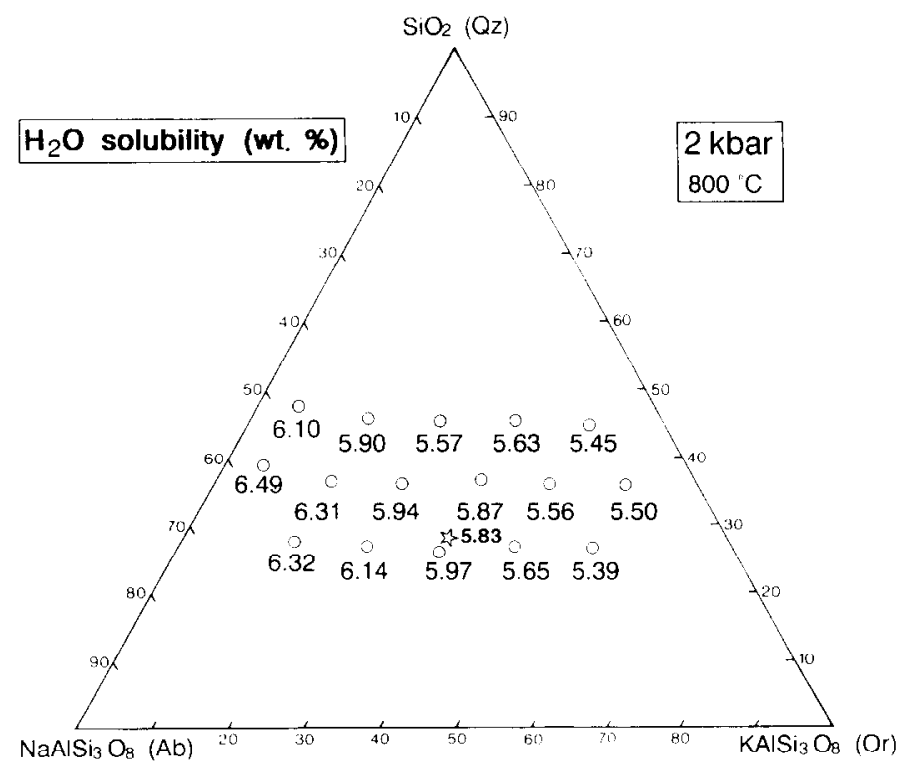

Fig. 1. $\mathrm{H}_{2} \mathrm{O}$ solubility, expressed as wt. $\% \mathrm{H}_{2} \mathrm{O}$, for 16 melt compositions (represented by dots) of the haplogranite system $\mathrm{Qz}-\mathrm{Ab}-\mathrm{Or}$ at $2 \mathrm{kbar}, 800^{\circ} \mathrm{C}$. The solubility value for each composition is indicated beneath the corresponding dot. The $\mathrm{Qz}, \mathrm{Ab}$ and $\mathrm{Or}$ contents of the investigated compositions are given as wt.\% normative proportions. All analytical data are given in Tables 1 and 2. The star represents the composition of Schott ${ }^{\circledR}$ glass $\left(\mathrm{Qz}_{28} \mathrm{Ab}_{38} \mathrm{Or}_{34}\right)$, for which the $T$ dependence of $\mathrm{H}_{2} \mathrm{O}$ solubility was investigated (see Fig. 3).

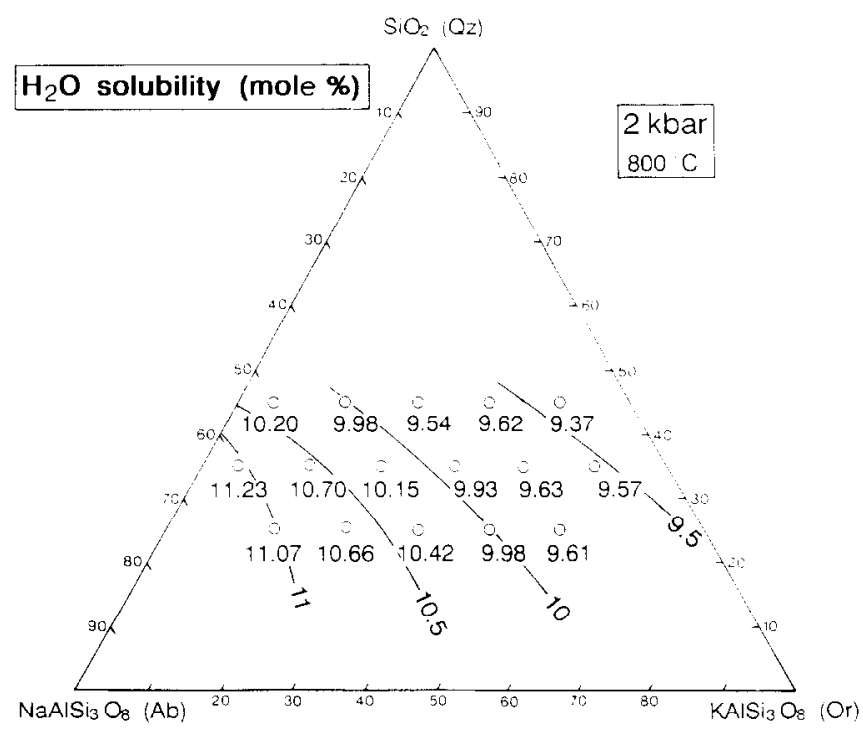

Fig. 2. $\mathrm{H}_{2} \mathrm{O}$ solubility, expressed as mole $\% \mathrm{H}_{2} \mathrm{O}$ (calculated on one oxygen basis), for 16 melt compositions of the haplogranite system $\mathrm{Qz}-\mathrm{Ab}-\mathrm{Or}$ at $2 \mathrm{kbar}, 800^{\circ} \mathrm{C}$. Lines correspond to $\mathrm{H}_{2} \mathrm{O}$ solubility isopleths (for further remarks, see Fig. $1)$. 
double-distilled $\mathrm{H}_{2} \mathrm{O}$. The amount of added $\mathrm{H}_{2} \mathrm{O}$ was chosen to be slightly higher than the expected solubility value $(6.5 \mathrm{wt} . \%$ for a composition $\mathrm{Qz}_{35} \mathrm{Ab}_{39} \mathrm{Or}_{26}$ at $685^{\circ} \mathrm{C}$ and 2 kbar; Luth, 1976). The capsules were checked for possible leakage by testing for weight loss after drying in an oven at $100^{\circ} \mathrm{C}$ for one to several hours. After such a period at $100^{\circ} \mathrm{C}$, the added water was considered to be distributed randomly into the gold capsule, and thus around the glass sample.

Three different methods were used to prepare the charges for the investigation of $T$ dependence. Some samples consisted of single glass blocks (see p.291). Other samples consisted of a glass block surrounded by a powder of glass, or only of glass powder (grain size of the powder: $200-500 \mu \mathrm{m}$ ).

The sealed capsules were placed, either in horizontal cold-seal pressure vessels (pressurized with $\mathrm{H}_{2} \mathrm{O}$ ) for experimental temperatures up to $850^{\circ} \mathrm{C}$, or in an internally heated gas pressure vessel (Ar as pressure medium) for temperatures of $>850^{\circ} \mathrm{C}$. The capsules were run at the desired $P$ and $T$ for sufficient time to allow complete diffusion of $\mathrm{H}_{2} \mathrm{O}$ through the sample (run duration ranging from 20 days to $10 \mathrm{hr}$ at $750^{\circ}$ and $1150^{\circ} \mathrm{C}$, respectively; see Tables 2 and 3 ). Considering diffusion coefficients of $\mathrm{H}_{2} \mathrm{O}$ of $10^{-8}$ to $10^{-7} \mathrm{~cm}^{2} \mathrm{~s}^{-1}$ (Lapham et al., 1984), it can be shown that run durations of 10-20 days as applied for the experiments between $750^{\circ}$ and $850^{\circ} \mathrm{C}$ are sufficient for complete diffusion of $\mathrm{H}_{2} \mathrm{O}$. However, it is worth noting that, if $\mathrm{H}_{2} \mathrm{O}$ is only located on one side of the glass block, the run duration necessary to obtain complete diffusion of $\mathrm{H}_{2} \mathrm{O}$ is four times higher than if $\mathrm{H}_{2} \mathrm{O}$ is equally distributed at both extremities of the capsule. Temperature was measured with a $\mathrm{Ni}-\mathrm{NiCr}$ thermocouple, and the actual temperatures are believed accurate to within $\pm 10^{\circ} \mathrm{C}$. Pressure was measured with a strain-gauge manometer (accuracy \pm 20 bar). Quenching in cold-seal pressure vessels was performed by using a flow of compressed air. Quenching in the inter- nally-heated pressure vessel was obtained by turning of the heating power. Special care was given to obtain an isobaric quench (for coldseal pressure vessels and internally-heated pressure vessels) by opening the vessel to the pressure line and by pumping regularly in order to maintain the pressure at a value of $2000 \pm 20$ bar.

\subsection{Analytical technique: Karl-Fischer titration}

The $\mathrm{H}_{2} \mathrm{O}$ content of the quenched glasses was determined by Karl-Fischer titration. KarlFischer titration is a well-known analytical procedure by which $\mathrm{H}_{2} \mathrm{O}$ reacts quantitatively, in presence of specific reagents, with coulometrically generated iodine (coulometer used for this study: Mitsubishi ${ }^{\circledR}$ CA 05 ). This procedure has been successfully applied to determine relatively high water contents in silicate materials (up to 5 wt.\%, e.g., Turek et al., 1976) as well as low $\mathrm{H}_{2} \mathrm{O}$ contents (down to 0.1 wt. $\% \mathrm{H}_{2} \mathrm{O}$, e.g., Westrich, 1987). Only small amounts of glass are necessary to get reliable data (typically 10-20 mg for substances containing $\sim 6$ wt. $\left.\% \mathrm{H}_{2} \mathrm{O}\right)$. The glass was roughly crushed and the $\mathrm{H}_{2} \mathrm{O}$ content was determined directly after crushing. This is necessary to avoid errors due to absorption of $\mathrm{H}_{2} \mathrm{O}$ for glasses with low $\mathrm{H}_{2} \mathrm{O}$ contents or due to desorption for glasses with high $\mathrm{H}_{2} \mathrm{O}$ contents. For one glass $\left(750^{\circ} \mathrm{C}, 2 \mathrm{kbar}\right) \mathrm{Karl}-\mathrm{Fischer} \mathrm{ti-}$ tration using both a single piece and a freshly crushed powder yielded nearly identical $\mathrm{H}_{2} \mathrm{O}$ contents (Table 3 ). This shows that crushing had no influence. The crushed glass was preferred to single pieces for the measurements since sputtering of the glass may occur by explosive liberation of $\mathrm{H}_{2} \mathrm{O}$ in the latter case. The glasses were heated progressively from $20^{\circ}$ to $1300^{\circ} \mathrm{C}$ using an induction furnace (typical rate for one measurement: $30^{\circ} \mathrm{C} \mathrm{min}{ }^{-1}$ from $20^{\circ}$ to $100^{\circ} \mathrm{C} ; 100^{\circ} \mathrm{C} \mathrm{min}^{-1}$ from $100^{\circ}$ to $400^{\circ} \mathrm{C} ; 50^{\circ} \mathrm{C} \mathrm{min}^{-1}$ from $400^{\circ}$ to $800^{\circ} \mathrm{C}$; 
TABLE 2

Results of $\mathrm{H}_{2} \mathrm{O}$ measurements by Karl-Fischer titration, and "preferred value" for $\mathrm{H}_{2} \mathrm{O}$ solubility at 2 kbar, $800^{\circ} \mathrm{C}$

\begin{tabular}{|c|c|c|c|c|c|c|}
\hline \multirow[t]{2}{*}{ No. } & \multicolumn{4}{|c|}{ Measured $\mathrm{H}_{2} \mathrm{O}$ contents } & \multicolumn{2}{|c|}{$\mathrm{H}_{2} \mathrm{O}$ solubility } \\
\hline & & & & & (wt.\%) & $($ mole $\%)$ \\
\hline HPG 1 & $6.50^{\mathrm{a}}$ & & $6.15^{b}$ & $6.30^{c}$ & 6.32 & 10.76 \\
\hline HPG 2 & $6.28^{\mathrm{a}}$ & & $6.00^{b}$ & $5.74^{c}$ & 6.14 & 10.42 \\
\hline HPG 3 & $6.03^{\mathrm{a}}$ & & $5.91^{b}$ & $5.74^{c}$ & 5.97 & 10.32 \\
\hline HPG4 & $5.71^{\mathrm{a}}$ & $5.68^{\mathrm{a}}$ & $5.62^{b}$ & $5.62^{\mathrm{c}}$ & 5.65 & 9.91 \\
\hline HPG 5 & $5.48^{\mathrm{a}}$ & & $5.30^{b}$ & $5.39^{c}$ & 5.39 & 9.45 \\
\hline HPG6 & $6.69^{\mathrm{a}}$ & & $6.31^{b}$ & $6.48^{c}$ & 6.49 & 10.89 \\
\hline HPG 7 & 6.31 & & & & 6.31 & 10.70 \\
\hline HPG 8 & 5.94 & & & & 5.94 & 10.15 \\
\hline HPG 9 & 5.87 & & & & 5.87 & 9.93 \\
\hline HPG 10 & 5.56 & & & & 5.56 & 9.63 \\
\hline HPG 11 & 5.50 & & & & 5.50 & 9.57 \\
\hline $\mathrm{HPG} 12$ & $6.13^{a}$ & $6.08^{a}$ & & & 6.10 & 10.30 \\
\hline HPG 13 & 5.90 & & & & 5.90 & 9.98 \\
\hline HPG 14 & 5.57 & & & & 5.57 & 9.54 \\
\hline HPG 15 & 5.63 & & & & 5.63 & 9.62 \\
\hline HPG 16 & 5.45 & & & & 5.45 & 9.37 \\
\hline Schott & see rest & e 3 & & & 5.83 & 9.92 \\
\hline
\end{tabular}

Run duration of the experiments was 10-20 days. Starting material was always a single dry glass cylinder. When $\mathrm{H}_{2} \mathrm{O}$ contents are followed by the same symbol $\left({ }^{\mathrm{a}}\right)$, measurements were performed from the same glass piece, when followed by different symbols $\left({ }^{a},{ }^{b}, c\right)$, measurements were performed from different glass pieces (test for reproducibility of the experiments).

$100^{\circ} \mathrm{C} \mathrm{min}^{-1}$ from $800^{\circ}$ to $1300^{\circ} \mathrm{C}$ ). The liberated $\mathrm{H}_{2} \mathrm{O}$ was transported by a dry Ar stream in the titration cell and is collected there. Titration started 4-6 min after beginning of the heating-up. The duration of the titration was 7-10 min.

The analytical precision for $\mathrm{H}_{2} \mathrm{O}$ is mainly dependent on the duration of the titration (7$10 \mathrm{~min}$ ) and can be estimated to be $\leqslant \pm 0.15$ wt.\% (for solubility values ranging between 6.7 and $5.4 \mathrm{wt} . \%$ ). Some analyses were duplicated (two measurements of coarse-grained powder obtained from the same glass piece) and the variation of $\mathrm{H}_{2} \mathrm{O}$ solubility is largely within the analytical precision given above. As an example, from two measurements performed with composition $\mathrm{Qz}_{45} \mathrm{Ab}_{50} \mathrm{Or}_{05}$ (HPG 12), $\mathrm{H}_{2} \mathrm{O}$ solubilities of 6.08 and $6.13 \mathrm{wt} \% \mathrm{H}_{2} \mathrm{O}$ were obtained (analytical data given in Table 2), corresponding to a variation of $0.8 \%$ relative. A variation of $0.6 \%$ relative $(5.71$ and 5.68 wt. $\% \mathrm{H}_{2} \mathrm{O}$ ) was obtained in doing the same test for composition $\mathrm{Qz}_{25} \mathrm{Ab}_{30} \mathrm{Or}_{45}$ (HPG 4). Variations of the same order of magnitude are obtained for composition $\mathrm{Qz}_{28} \mathrm{Ab}_{38} \mathrm{Or}_{34}$ for which the $T$ dependence of $\mathrm{H}_{2} \mathrm{O}$ solubility was investigated. In this case analyses were duplicated (or triplicated) systematically for $10 \mathrm{ex}$ perimental products (see analytical data in Table 3).

\section{Results}

\subsection{Run products}

The quenched run products consisted of bubble- and crystal-free limpid glasses. In experiments with single glass cylinders as starting material, the shape of the glass pieces after hydration were similar to those of the starting glass cylinders except for surface "healing" of the drill marks. The glasses obtained from charges consisting of a glass block plus glass 
TABLE 3

Results of $\mathrm{H}_{2} \mathrm{O}$ measurements by Karl-Fischer titration, and "preferred value" for $\mathrm{H}_{2} \mathrm{O}$ solubility at 2 kbar, for composition $\mathrm{Qz}_{28} \mathrm{Ab}_{38} \mathrm{Or}_{34}$

\begin{tabular}{|c|c|c|c|c|c|c|c|c|}
\hline \multirow[t]{2}{*}{ No. } & \multirow{2}{*}{$\begin{array}{l}T \\
\left({ }^{\circ} \mathrm{C}\right)\end{array}$} & \multirow[t]{2}{*}{ SM } & \multirow{2}{*}{$\begin{array}{l}\text { Duration } \\
\text { (hr) }\end{array}$} & \multicolumn{3}{|c|}{ Measured $\mathrm{H}_{2} \mathrm{O}$ contents } & \multicolumn{2}{|c|}{$\mathrm{H}_{2} \mathrm{O}$ solubility } \\
\hline & & & & & & & (wt.\%) & $($ mole $\%)$ \\
\hline 048 & 750 & $\mathrm{bp}$ & 336 & 5.97 & $6.03^{*}$ & & 6.00 & 10.25 \\
\hline 036 & 800 & $\mathrm{bp}$ & 336 & 5.80 & 5.75 & & 5.77 & 9.84 \\
\hline 060 & 800 & $b^{*}$ & 360 & 5.85 & 5.86 & & 5.86 & 9.99 \\
\hline 061 & 800 & $\mathrm{bp}$ & 360 & 5.87 & 5.81 & & 5.84 & 9.96 \\
\hline 019 & 850 & $\mathrm{~b}$ & 46 & 5.70 & 5.76 & & 5.73 & 9.79 \\
\hline 042 & 900 & $\mathrm{bp}$ & 192 & 5.79 & 5.81 & & 5.80 & 9.91 \\
\hline 053 & 950 & $\mathrm{bp}$ & 120 & 5.67 & 5.32 & 5.46 & 5.48 & 9.36 \\
\hline 037 & 1,000 & $\mathrm{p}$ & 110 & 5.50 & 5.41 & & 5.45 & 9.31 \\
\hline 021 & 1,050 & b & 15 & 5.53 & 5.61 & & 5.57 & 9.52 \\
\hline 044 & 1,100 & $\mathrm{bp}$ & 90 & 5.13 & 5.49 & & 5.31 & 9.07 \\
\hline 002 & 1,150 & $\mathrm{p}$ & 96 & 5.31 & 5.29 & 5.44 & 5.35 & 9.14 \\
\hline 028 & 1,150 & $\mathrm{p}$ & 20 & 5.53 & 5.41 & & 5.47 & 9.35 \\
\hline
\end{tabular}

Each measurement was made using a complete slice of glass ( $1 \mathrm{~mm}$ thickness) cutted from the glass block obtained after the experiment ( see text). $\mathbf{S M}=$ starting material $(b=$ glass block; $p=$ glass powder; $b p=$ glass block surrounded by glass powder $)$.

*Titration performed using a single glass piece. For the other analyses, titration performed on roughly crushed glass fragments.

powder or only glass powder were also free of bubbles.

\subsection{Homogeneity of $\mathrm{H}_{2} \mathrm{O}$ distribution in glasses}

The homogeneity of the glasses was tested in two ways. Some large glass samples $(7-10 \mathrm{~mm}$ length; $3 \mathrm{~mm}$ diameter) were cut in slices of $\sim 1 \mathrm{~mm}$ thickness, perpendicular to the capsule elongation. Each slice was analyzed individually by Karl-Fischer titration. The water contents given in Table 3 result from analyses performed in this way and show good homogeneities of the quenched melts. Some other samples, initially consisting of single glass pieces as well as glass block plus powder, were analyzed with an infrared microscope (Bru$\mathrm{ker}^{\circledast}$ A590 with spectrometer IFS 88). Several measurements were performed from the rim to the core of the glass pieces. Local resolution of the measurements was $\sim 100 \mu \mathrm{m}$. There was no significant change in the background subtracted peak height, at $4500 \mathrm{~cm}^{-1}$ (due to hydroxyl groups) and at $5230 \mathrm{~cm}^{-1}$ (due to mo- lecular $\mathrm{H}_{2} \mathrm{O}$ ), suggesting that $\mathrm{H}_{2} \mathrm{O}$ is homogeneously distributed throughout the sample and that the run durations were long enough to produce complete hydration of the sample.

\subsection{Reproducibility of the experiments}

The reproducibility of our solubility experiments was tested for seven compositions. For these compositions the experiments (and hence the analysis of $\mathrm{H}_{2} \mathrm{O}$ content of the glass) were repeated (triplicates or duplicates). In the case of six compositions $\left(\mathrm{Qz}_{25} \mathrm{Ab}_{60} \mathrm{Or}_{15}\right.$, $\mathrm{Qz}_{25} \mathrm{Ab}_{40} \mathrm{Or}_{35}, \mathrm{Qz}_{25} \mathrm{Ab}_{30} \mathrm{Or}_{45}, \mathrm{Qz}_{25} \mathrm{Ab}_{20} \mathrm{Or}_{55}$, $\mathrm{Qz}_{35} \mathrm{Ab}_{60} \mathrm{Or}_{05}, \mathrm{Qz}_{28} \mathrm{Ab}_{38} \mathrm{Or}_{34}$ ), the maximum difference between two analyzed $\mathrm{H}_{2} \mathrm{O}$ contents is 0.38 wt. $\% \mathrm{H}_{2} \mathrm{O}$ (Tables 2 and 3 ), which corresponds to a variation of $5.8 \%$ relative or less of the $\mathrm{H}_{2} \mathrm{O}$ solubility value. Thus the uncertainity due to the reproducibility of our experiments appears to be more important than that due to the analytical method (see p.294). The more important variation observed for one 
composition $\left(\mathrm{Qz}_{25} \mathrm{Ab}_{50} \mathrm{Or}_{25}\right.$, difference of 0.54 wt. $\% \mathrm{H}_{2} \mathrm{O}$, see Table 2 ) is attributed either to a bad distribution of water in the capsule during the experiment in case of the sample with the lowest $\mathrm{H}_{2} \mathrm{O}$ content (part of the water was probably not in contact with the glass sample and was isolated on one side of the capsule) or to incomplete diffusion. Therefore, in this case only the two highest values were averaged to calculate the "preferred" solubility value in Table 2. It is worth noting that the $\mathrm{H}_{2} \mathrm{O}$ content of the sample is not only dependent on the run duration but also on the location of the 10 wt. $\%$ added $\mathrm{H}_{2} \mathrm{O}$ in the capsule before the experiment, a factor which is difficult to control.

\subsection{Compositional dependence of the $\mathrm{H}_{2} \mathrm{O}$ solubility at $800^{\circ} \mathrm{C}$}

Solubility values at $800^{\circ} \mathrm{C}$ are given in Table 2 for the sixteen investigated compositions. The $\mathrm{H}_{2} \mathrm{O}$ solubility values expressed as wt. $\% \mathrm{H}_{2} \mathrm{O}$ are also plotted in Fig. 1. The $\mathrm{H}_{2} \mathrm{O}$ solubilities expressed as mole\% (one oxygen basis ) are illustrated in Fig. 2. $\mathrm{H}_{2} \mathrm{O}$ solubility is dependent on anhydrous melt composition; the highest values are obtained for Ab-rich compositions (6.49 and 6.32 wt.\% $\mathrm{H}_{2} \mathrm{O}$ for compositions with $60 \mathrm{wt} . \%$ normative $\mathrm{Ab}$ ), and the lowest for Or-rich compositions (5.50 and $5.39 \mathrm{wt} . \% \mathrm{H}_{2} \mathrm{O}$ for compositions with 60 wt. \% normative Or).

At constant $\mathrm{Qz}$ content $\mathrm{H}_{2} \mathrm{O}$ solubility decreases with decreasing $\mathrm{Ab}$ content in the melt (Fig. 1), in agreement with solubility data for alkali feldspar melts obtained by Oxtoby and Hamilton (1978b) and Voigt et al. (1981). The difference in $\mathrm{H}_{2} \mathrm{O}$ solubility between $\mathrm{Ab}$ and Or-rich melts is more pronounced for compositions with lower quartz contents (difference of 0.65 and 0.99 wt. $\% \mathrm{H}_{2} \mathrm{O}$ between compositions $\mathrm{Qz}_{45} \mathrm{Ab}_{50} \mathrm{Or}_{05} / \mathrm{Qz}_{45} \mathrm{Ab}_{10} \mathrm{Or}_{45}$ and $\mathrm{Qz}_{35} \mathrm{Ab}_{60} \mathrm{Or}_{05} / \mathrm{Qz}_{35} \mathrm{Ab}_{10} \mathrm{Or}_{55}$, respectively).

At constant Or content there is a marked increase in $\mathrm{H}_{2} \mathrm{O}$ solubility with increasing $\mathrm{Ab}$ content (decreasing $\mathrm{Qz}$ content) in case of $\mathrm{Ab}$ - rich melts $\left(\mathrm{H}_{2} \mathrm{O}\right.$ solubility in melts with 15 wt.\% normative Or: 5.90 wt. $\% \mathrm{H}_{2} \mathrm{O}$ for composition $\mathrm{Qz}_{45} \mathrm{Ab}_{40} \mathrm{Or}_{15}, 6.32$ wt.\% $\mathrm{H}_{2} \mathrm{O}$ for composition $\mathrm{Qz}_{25} \mathrm{Ab}_{60} \mathrm{Or}_{15}$ ). In contrast, the variation of $\mathrm{H}_{2} \mathrm{O}$ solubility in Or-rich melts is much lower $\left(\mathrm{H}_{2} \mathrm{O}\right.$ solubility value between 5.65 and 5.39 for melts containing more or as much as 45 wt.\% normative Or content). However, even for Or-rich melts, a small increase in $\mathrm{H}_{2} \mathrm{O}$ solubility with increasing $\mathrm{Na}$ content (decreasing $\mathrm{Qz}$ ) at constant Or content is observed $\left(\mathrm{H}_{2} \mathrm{O}\right.$ increases from 5.45 for composition $\mathrm{Qz}_{45} \mathrm{Ab}_{10} \mathrm{Or}_{45}$ to 5.65 for composition $\mathrm{Qz}_{25} \mathrm{Ab}_{30} \mathrm{Or}_{45}$ ).

At constant $\mathrm{Ab}$ content there is no systematic dependence of the $\mathrm{H}_{2} \mathrm{O}$ solubility on $\mathrm{Qz}$ (or Or) content. The changes in $\mathrm{H}_{2} \mathrm{O}$ solubility values are much less important than for sections at constant $\mathrm{Qz}$ content or for sections at constant $\mathrm{Or}$ contents and high $\mathrm{Ab} /$ $(\mathrm{Ab}+\mathrm{Or})$ ratios.

\subsection{Temperature dependence of the $\mathrm{H}_{2} \mathrm{O}$ solubility for composition $Q z_{28} \mathrm{Ab}_{38} \mathrm{Or}_{34}$}

The $\mathrm{H}_{2} \mathrm{O}$ contents of the analyzed glasses and the $\mathrm{H}_{2} \mathrm{O}$ solubility values for composition $\mathrm{Qz}_{28} \mathrm{Ab}_{38} \mathrm{Or}_{34}$ are given in Table 3 and plotted in Fig. 3. There is a small decrease in $\mathrm{H}_{2} \mathrm{O}$ solubility from 6.00 to $5.41 \mathrm{wt} \% \mathrm{H}_{2} \mathrm{O}$ with increasing $T$ from $750^{\circ}$ to $1150^{\circ} \mathrm{C}$. Although obtained by the use of three different starting materials (single glass piece, glass + powder, powder), the results are internally consistent. At $800^{\circ} \mathrm{C}$, with the starting material consisting of a glass block plus glass powder, the $\mathrm{H}_{2} \mathrm{O}$ solubility is $5.83 \mathrm{wt} . \% \mathrm{H}_{2} \mathrm{O}$. The composition with approximately the same Qz:Ab:Or ratio $\left(\mathrm{Qz}_{25} \mathrm{Ab}_{40} \mathrm{Or}_{35}\right.$ or HPG 3), determined from a glass cylinder only, yielded a solubility value of 5.97 (see Fig. 1), suggesting a good agreement between solubility values determined from similar starting material but with different ways of sample preparation. 


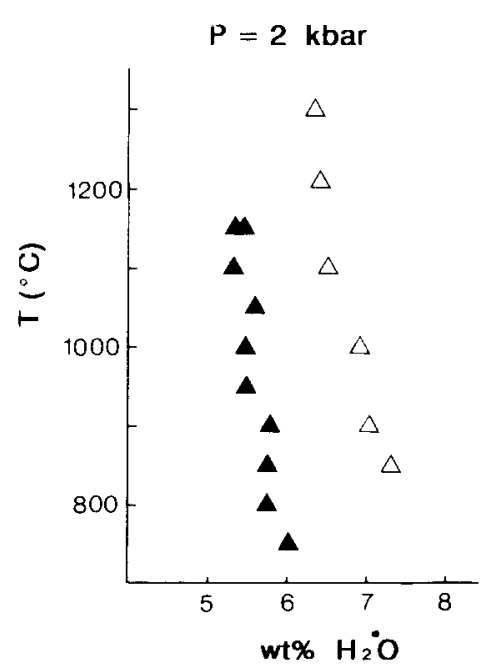

Fig. 3. Temperature dependence of $\mathrm{H}_{2} \mathrm{O}$ solubility at $2 \mathrm{kbar}$ for a melt with a composition $\mathrm{Qz}_{28} \mathrm{Ab}_{38} \mathrm{Or}_{34}$ (solid triangles). For comparison data of Hamilton and Oxtoby (1986) for albite melts at 2 kbar have been reported (open triangles). Analytical data are given in Table 3.

\section{Discussion}

\subsection{Comparison with previous data}

Although the acquisition of $\mathrm{H}_{2} \mathrm{O}$ solubility data for aluminosilicate melts of granitic composition has been the focus of several studies, the present data for haplogranite melts are comparable with only a very few of them. This results from a difference in experimental strategy. Almost all the previous studies: (1) have used a single melt composition, commonly either that of albite (e.g., Goranson, 1931; Burnham and Jahns, 1962; Orlova, 1963; Oxtoby and Hamilton, 1978b; Blamart et al., 1988), or of a complex natural rock type such as Harding Pegmatite, New Mexico, U.S.A. (Burnham and Jahns, 1962); and (2) have focused their efforts upon describing the variation of $\mathrm{H}_{2} \mathrm{O}$ solubility as a function of either pressure or temperature (or both). In contrast our principal objective has been to measure the variation of $\mathrm{H}_{2} \mathrm{O}$ solubility in a large number of simple melt compositions under isobaric and isothermal conditions, with a view to documenting precisely the compositional depen- dence of $\mathrm{H}_{2} \mathrm{O}$ solubility. A direct comparison of our results with those of the previous studies is therefore impossible.

However, some broad comparisons are possible. $\mathrm{H}_{2} \mathrm{O}$ solubility measurements in the system $\mathrm{Qz}-\mathrm{Ab}$-Or have been conducted primarily for the end-members and also for compositions close to the thermal minimum. Although there are some significant differences in the measured $\mathrm{H}_{2} \mathrm{O}$ concentrations that have been reported in these studies for specific compositions (especially for albite melts, the most studied composition), the preferential dissolution of $\mathrm{H}_{2} \mathrm{O}$ in $\mathrm{Ab}$-rich melts by comparison to Or-rich melts has been observed consistently (see Oxtoby and Hamilton, 1978b; Voigt et al., 1981; and the review in McMillan and Holloway, 1987). In a similar way, an examination of the solubility of $\mathrm{H}_{2} \mathrm{O}$ in cotectic compositions in the system $\mathrm{Qz}-\mathrm{Ab}-\mathrm{Or}$ at $2 \mathrm{kbar}$ (i.e. compositions along the quartz-feldspar boundary) indicates that the solubility increases from $5.6 \mathrm{wt} . \% \mathrm{H}_{2} \mathrm{O}$ for the $\mathrm{Qz}-\mathrm{Or}$ eutectic composition, to $6.5 \mathrm{wt} . \% \mathrm{H}_{2} \mathrm{O}$ for the minimum composition, to $>7 \mathrm{wt} . \% \mathrm{H}_{2} \mathrm{O}$ for the $\mathrm{Qz}-\mathrm{Ab}$ eutectic composition $\left(\mathrm{H}_{2} \mathrm{O}\right.$ solubility data of Tuttle and Bowen, 1958 compiled in Luth, 1976). Although our $\mathrm{H}_{2} \mathrm{O}$ solubility data yield slightly lower values $(\sim 0.5 \mathrm{wt} . \%$ $\mathrm{H}_{2} \mathrm{O}$ less for the minimum composition) the general evolutionary trend summarized in Luth (1976) is remarkably consistent with that of increasing $\mathrm{H}_{2} \mathrm{O}$ solubility in more Ab-rich melts shown by our data.

Although the compositional dependence of $\mathrm{H}_{2} \mathrm{O}$ solubility in haplogranite melts was the focus of the present study, a series of experiments were conducted to investigate the effects of $T$ on one selected sample $\left(\mathrm{Qz}_{28} \mathrm{Ab}_{38} \mathrm{Or}_{34}\right)$. The results are given in Table 3. There is a slight decrease of $\mathrm{H}_{2} \mathrm{O}$ solubility with increasing $T$ (Fig. 3 ). Although the solubility of $\mathrm{H}_{2} \mathrm{O}$ is higher in albite melts at any given $T$ (e.g., $7.3 \mathrm{wt} . \% \mathrm{H}_{2} \mathrm{O}$ at $850^{\circ} \mathrm{C}$ in albite in comparison to $5.73 \mathrm{wt} . \% \mathrm{H}_{2} \mathrm{O}$ in our haplogranite melt), the slope of the trend observed 
with increasing $T$ (Fig. 3 ) is very similar for melts of both albite and haplogranite of composition $\mathrm{Qz}_{28} \mathrm{Ab}_{38} \mathrm{Or}_{34}$. Such a relationship suggests that $\mathrm{H}_{2} \mathrm{O}$ solubility data obtained at a given $T$ can be extrapolated to other temperatures, at least for 2 kbar and compositions with $\mathrm{Ab}$ contents between 100 and 35 normative weight percent.

The $\mathrm{H}_{2} \mathrm{O}$ solubility data (at $\sim 2$ kbar) for natural granitic rocks with comparable bulk compositions to those of our experimental melts are extremely limited in number; they include those for the Harding Pegmatite $\left(\mathrm{Qz}_{45} \mathrm{Ab}_{37} \mathrm{Or}_{18}\right)$ with measured solubilities of 6.0-6.8 wt. $\% \mathrm{H}_{2} \mathrm{O}$ at $T=670^{\circ} \mathrm{C}$ (Burnham and Jahns, 1962). Although such values are quite similar to those of the solubility field at $T=800^{\circ} \mathrm{C}$ as defined in this study (Fig. 2), any direct comparison with the $\mathrm{H}_{2} \mathrm{O}$ solubility data for the Harding Pegmatite is impeded by the significant concentrations of other volatiles, specifically $\mathrm{Li}$ and $\mathrm{F}$, which the pegmatite melt is known to contain (Burnham and Jahns, 1962 , table 1), and also by the peraluminous character (normative corundum $=2.4 \mathrm{wt} . \%$ ) of the pegmatite.

\subsection{Importance for $\mathrm{H}_{2} \mathrm{O}$ solubility mechanisms in aluminosilicate melts}

Our experimental results constitute the first systematic set of data demonstrating the isobaric, isothermal effect of composition on $\mathrm{H}_{2} \mathrm{O}$ solubility in the $\mathrm{Qz}-\mathrm{Ab}-\mathrm{Or}$ system. Thus, they provide important constraints on the solubility mechanisms of $\mathrm{H}_{2} \mathrm{O}$ in quartzofeldspathic melts. The changes in $\mathrm{H}_{2} \mathrm{O}$ solubility are characterized by: (1) a marked contrast between Qz-Ab- and Qz-Or-rich melts, with $\mathrm{H}_{2} \mathrm{O}$ solubility varying significantly in $\mathrm{Qz}-\mathrm{Ab}$-rich melts but remaining near constant in $\mathrm{Qz}-\mathrm{Or}$ rich melts; and (2) a significant increase in $\mathrm{H}_{2} \mathrm{O}$ solubility with increasing $\mathrm{Ab}$ content, either at the expense of Or (constant $\mathrm{Qz}$ ) or at the expense of Qz (constant Or). By contrast there is no systematic and substantial varia- tion of $\mathrm{H}_{2} \mathrm{O}$ solubility for melt compositions with constant $\mathrm{Ab}$ content. These data suggest that the effect of exchanging $\mathrm{Na}$ and $\mathrm{K}$ in haplogranitic melts may strongly influence the $\mathrm{H}_{2} \mathrm{O}$ solubility and, hence, $\mathrm{H}_{2} \mathrm{O}$ dissolution mechanism.

In most of the models seeking to explain the incorporation of $\mathrm{H}_{2} \mathrm{O}$ in aluminosilicate melts (e.g., Burnham, 1981; Kohn et al., 1989) it has been suggested that an exchange between M (M for $\mathrm{K}, \mathrm{Na}$ ), balancing the charge of the $\mathrm{Al}$ atom, and $\mathrm{H}$ cations (either from $\mathrm{OH}$ or $\mathrm{H}_{2} \mathrm{O}$ ) takes place (see Pichavant et al., 1992 in this issue for a review). Our solubility data suggest that the exchange of $\mathrm{M}$ for $\mathrm{H}$ is more important in the case of $\mathrm{Na}$ than of $\mathrm{K}$ (higher solubility for Na-rich melts) and that $\mathrm{K}$ has a relatively "passive" role when compared to $\mathrm{Na}$ (strong variation of solubility data for Na-rich melts, almost constant values for $\mathrm{K}$-rich melts ). The very low ability of exchange of K-bearing units has been confirmed by Holtz et al. (1992) and Pichavant et al. ( 1992 in this issue) investigating liquidus phase relationships in the system $\mathrm{Qz}-\mathrm{Ab}$-Or under $\mathrm{H}_{2} \mathrm{O}$-saturated and -undersaturated conditions (at constant $P$ ). With decreasing $\mathrm{H}_{2} \mathrm{O}$ content of the melt (decreasing $a_{\mathrm{H}_{2} \mathrm{O}}$ ) liquidus temperatures for quartz and alkali feldspar increase significantly, with the magnitude of the temperature increase being more marked for $\mathrm{Qz}-\mathrm{Ab}$-rich than for $\mathrm{Qz}-\mathrm{Or}$ rich compositions, thus confirming the preferential association of $\mathrm{Na}$ with $\mathrm{H}_{2} \mathrm{O}$ ( see also Pichavant, 1987).

Amongst the recent $\mathrm{H}_{2} \mathrm{O}$ speciation models, there is now overall agreement that water is present as both molecular $\mathrm{H}_{2} \mathrm{O}$ and $\mathrm{OH}$ groups (e.g., Silver and Stolper, 1989; Silver et al., 1990). However, the amounts of both species present in the melt is still under discussion. Stolper and coworkers, on the basis of spectroscopic studies of quenched glasses, suggest that there is a solubility maximum for water incorporated as $\mathrm{OH}$ groups at $1.7-2.3$ wt. $\% \mathrm{H}_{2} \mathrm{O}$. This maximum is attained for a total water content of $\sim 4$ wt. $\% \mathrm{H}_{2} \mathrm{O}$. At $\mathrm{H}_{2} \mathrm{O}$ contents 
higher than $4 \mathrm{wt} . \%$, all additional water is incorporated as molecular $\mathrm{H}_{2} \mathrm{O}$. Since our melts all contain more than 4 wt. $\% \mathrm{H}_{2} \mathrm{O}$, their $\mathrm{OH}$ content should correspond to the maximum value, according to Stolper and coworkers' measurements. The maximum amount of $\mathrm{H}_{2} \mathrm{O}$ incorporated as $\mathrm{OH}$ groups is thus $2.3 \mathrm{wt} . \%$ $\mathrm{H}_{2} \mathrm{O}$ in $\mathrm{Ab}$ melts (Silver and Stolper, 1989) and 2 wt. $\% \mathrm{H}_{2} \mathrm{O}$ in Or melts (Silver et al., 1990).

Consequently the difference in solubility between $\mathrm{Ab}$ and Or melts is only of the order of $0.3 \mathrm{wt} . \% \mathrm{H}_{2} \mathrm{O}$ dissolved as $\mathrm{OH}$ groups. Considering our compositions, the difference between $\mathrm{Qz}-\mathrm{Ab}$ and $\mathrm{Qz}-\mathrm{Or}$ melts should be even lower. Thus, according to Stolper and coworkers' model, the higher $\mathrm{H}_{2} \mathrm{O}$ solubilities observed in our Na-rich melts $(\sim 1 \mathrm{wt} . \%$ more $\mathrm{H}_{2} \mathrm{O}$ dissolved in Na-rich than in K-rich melts; see, e.g., difference of $\mathrm{H}_{2} \mathrm{O}$ solubility between compositions $\mathrm{Qz}_{35} \mathrm{Ab}_{60} \mathrm{Or}_{05}$ and $\mathrm{Qz}_{35} \mathrm{Ab}_{10} \mathrm{Or}_{45}$, Table 1) should be related to the higher amounts of molecular $\mathrm{H}_{2} \mathrm{O}$ in these melts. This means that the incorporation mechanisms of molecular water should be strongly dependent on the melt composition $(\mathrm{Na} / \mathrm{K}$ ratio $)$. In addition, there are also arguments showing that the melt composition has a significant effect on the amount of water dissolved as $\mathrm{OH}$ groups. For example, $\mathrm{H}_{2} \mathrm{O}$ solubility data for $\mathrm{Qz}, \mathrm{Ab}$, Or and Qz-Ab melts (Kennedy et al., 1962; Oxtoby and Hamilton, 1978a, b; see review in McMillan and Holloway, 1987) indicate that the difference in $\mathrm{H}_{2} \mathrm{O}$ solubility between melts of different compositions strongly increases with increasing pressure from 0 to $2 \mathrm{kbar}$ (i.e. at low $\mathrm{H}_{2} \mathrm{O}$ contents and thus for high proportions of $\mathrm{OH}$ groups) whereas this difference remains almost constant for pressures between 2 and 10 kbar (i.e. when most of $\mathrm{H}_{2} \mathrm{O}$ is supposed to be incorporated as molecular $\mathrm{H}_{2} \mathrm{O}$ ).

More recent work indicates that the disproportionation of $\mathrm{H}_{2} \mathrm{O}$ recorded in silicate glasses can be strongly quench-rate dependent (Dingwell and Webb, 1990a; Silver et al., 1990). This dependence upon the quench rate indicates a strong temperature dependence of the speciation, and comparable estimates of a reaction enthalpy of $25 \mathrm{~kJ} \mathrm{~mol}^{-1}$ have been obtained using quite different methods (Dingwell and Webb, 1989, 1990b; Silver and Stolper, 1989; Zhang et al., 1991). One important consequence of the temperature dependence of $\mathrm{H}_{2} \mathrm{O}$ speciation is that speciation data must be corrected to fictive temperature (i.e. the structural temperature frozen into the glass during the quench). Such estimates result in much higher concentrations of $\mathrm{OH}$ in rhyolite melt $+5 \mathrm{wt} . \% \mathrm{H}_{2} \mathrm{O}$ at $800^{\circ} \mathrm{C}$, for example, than are quenched in at the glass transition of this material during hydrothermal quenches (Dingwell and Webb, 1989, 1990b). The result is that $\mathrm{OH}$ groups may still dominate the speciation of $\mathrm{H}_{2} \mathrm{O}$ in the present glassses at temperature and thus the composition dependence of the $\mathrm{H}_{2} \mathrm{O}$ solubility may originate in the relative stability of various $\mathrm{OH}$ species rather than molecular $\mathrm{H}_{2} \mathrm{O}$.

The temperature dependence of the solubility of water can be compared with the temperature dependence of water-speciation to gain further insight into the mechanisms of water solution in these melts. The temperature dependence of water solubility in the Schott ${ }^{\circledast}$ glass is illustrated in Fig. 3. These data are described by: wt. \% $\mathrm{H}_{2} \mathrm{O}=(6.92 \pm 0.13) \quad-$ $(0.00137 \pm 0.00021) T$ where wt. $\% \mathrm{H}_{2} \mathrm{O}$ refers to the total dissolved water; and $T$ is the temperature in ${ }^{\circ} \mathrm{C}$. (Standard deviations are indicated for the equation.) The temperature-dependent proportions of $\mathrm{OH}$ and $\mathrm{H}_{2} \mathrm{O}$ dissolved in this melt may be estimated from the relaxation analysis of Dingwell and Webb (1989, 1990b) for a natural rhyolite (Silver and Stolper, 1989). The results of that analysis yield disproportionation values (molar fraction of $\mathrm{OH} / 2$ to $\mathrm{H}_{2} \mathrm{O}$ ) equal to 0.48 at $750^{\circ} \mathrm{C}$ and 0.62 at $1150^{\circ} \mathrm{C}$ (from data given in Table 3 ). These values yield, in turn, temperature-dependent values for the wt.\% of water dissolved as hydroxyl and as molecular $\mathrm{H}_{2} \mathrm{O}$ as functions of temperature. Hydroxyl content shows little or 
no temperature dependence (recalling analytical errors of $\pm 0.15 \%)$. Molecular water in contrast shows a strongly negative temperature-dependent solubility.

\subsection{Geological implications}

The $\mathrm{H}_{2} \mathrm{O}$ solubility data presented in this paper may have important petrological implications concerning both physical and chemical properties of granitic melts. The viscosity of silicate melts is known to be dramatically dependent on the $\mathrm{H}_{2} \mathrm{O}$ content of melts (e.g., Burnham, 1963; Friedman et al., 1963; Dingwell, 1987). The higher $\mathrm{H}_{2} \mathrm{O}$ solubility in $\mathrm{Na}$ rich melts demonstrated here implies that these melts are less viscous than K-rich ones (in $\mathrm{H}_{2} \mathrm{O}$-saturated conditions). In addition, Urbain et al. (1984) have shown that $\mathrm{KAlSi}_{3} \mathrm{O}_{8}$ liquids are more viscous than $\mathrm{NaAlSi}_{3} \mathrm{O}_{8}$ liquids at the same temperature. In natural magmatic processes, $\mathrm{H}_{2} \mathrm{O}$-saturated melts mainly occur at the end of the crystallization history as aplitic dykes, corresponding to residual melts. This mode of emplacement (dykes) only occurs if the viscosity of the melts is relatively low. Our results suggest that residual $\mathrm{Na}$-rich melts are better candidates to form dykes than $\mathrm{K}$-rich residual melts. Investigations of leucogranitic rocks associated with dyke swarms show that these leucogranites are very often rich in $\mathrm{Na}$ and $\mathrm{Al}$ (e.g., Nabelek et al., 1992).

As already mentioned by Pichavant (1990), the compositional dependence of $\mathrm{H}_{2} \mathrm{O}$ solubility in the $\mathrm{Qz}-\mathrm{Ab}-\mathrm{Or}$ system implies that phase relations in this system have to be reconsidered if they are used to interpret the composition and formation of granitic rocks. Liquidus phase relations in the system Qz-Ab-Or, currently used in petrology and determined by Tuttle and Bowen (1958) and Luth et al. (1964), are presented as isobaric polythermal sections, in which the $\mathrm{H}_{2} \mathrm{O}$ content of the melts is not considered. Obviously, the position of the liquidus surface will be strongly changed if a $\mathrm{Qz}-\mathrm{Ab}-\mathrm{Or}$ section is constructed at constant pressure and $\mathrm{H}_{2} \mathrm{O}$ content of the melt. For example, in the case of a section at 2 kbar with 5 wt.\% $\mathrm{H}_{2} \mathrm{O}$ in the melt, a $\mathrm{Qz}-\mathrm{Or}$ eutectic melt would be slightly $\mathrm{H}_{2} \mathrm{O}$-undersaturated (melts are saturated with respect to $\mathrm{H}_{2} \mathrm{O}$ for values close to $5 \mathrm{wt} . \% \mathrm{H}_{2} \mathrm{O}$ at $800^{\circ} \mathrm{C}$ ), whereas a Qz$\mathrm{Ab}$ eutectic melt would be strongly $\mathrm{H}_{2} \mathrm{O}$-undersaturated $\left(\mathrm{H}_{2} \mathrm{O}\right.$ solubility at $800^{\circ} \mathrm{C}$ close to $7 \mathrm{wt} . \% \mathrm{H}_{2} \mathrm{O}$ ). This in turn implies that, for a $\mathrm{H}_{2} \mathrm{O}$ content of the melt of $5 \mathrm{wt} . \%$, liquidus temperatures for $\mathrm{Qz}-\mathrm{Ab}$-rich melts will be considerably higher than that given in the 2kbar $\mathrm{H}_{2} \mathrm{O}$-saturated section of Tuttle and Bowen (1958), whereas they will be almost similar for Qz-Or-rich melts. More generally, the compositional dependence of the solubility of $\mathrm{H}_{2} \mathrm{O}$ in the haplogranite system allows one to quantitatively describe the process of crystallization-induced saturation or "second boiling". It is clear from Fig. 1 that crystallization trends on the quartz-feldspar cotectic could either increase or decrease the solubility of $\mathrm{H}_{2} \mathrm{O}$ in the resultant melt phase depending on the alkali distribution between feldspar and melt.

In this study, the temperature dependence of $\mathrm{H}_{2} \mathrm{O}$ solubility was investigated for a composition close to the minimum melt composition at a $\mathrm{PH}_{2} \mathrm{O}$ of $2 \mathrm{kbar}$, allowing good comparison of our data with granitic rocks. The $\mathrm{H}_{2} \mathrm{O}$ solubility variation between $750^{\circ}$ and $1150^{\circ} \mathrm{C}$ is relatively low and corresponds to $0.6 \mathrm{wt} . \%$ $\mathrm{H}_{2} \mathrm{O}$. With the formation of most crustal granitic rocks occurring at temperatures below $850^{\circ} \mathrm{C}$, it would appear that the increase of $\mathrm{H}_{2} \mathrm{O}$ solubility in melts due to cooling is negligible, with the most important factor controlling the $\mathrm{H}_{2} \mathrm{O}$ solubility in cooling, ascending melts being pressure. In addition, however, the results of this study show that the role of melt composition on $\mathrm{H}_{2} \mathrm{O}$ solubility is significantly more important than the role of temperature especially for albite-rich melts.

\section{Conclusions}

Though the aim of this work is not to consider in detail the bonding of $\mathrm{H}_{2} \mathrm{O}$ in silicate 
melts or the structure of silicate melts, our results clearly show: (1) the preferential association of $\mathrm{Na}$ with $\mathrm{H}_{2} \mathrm{O}$, demonstrated by increasing $\mathrm{H}_{2} \mathrm{O}$ solubilities with increasing $\mathrm{Ab}$ content of the melt (especially in case of Narich melts ); and (2) the relatively passive role of $\mathrm{K}$ for the incorporation mechanisms of $\mathrm{H}_{2} \mathrm{O}$, demonstrated by the low variations of $\mathrm{H}_{2} \mathrm{O}$ solubility in K-rich melts. Future theories on the structure of hydrous melts should account for the results presented here.

The significant variation in $\mathrm{H}_{2} \mathrm{O}$ solubility in the $\mathrm{Qz}-\mathrm{Ab}-\mathrm{Or}$ system as a function of the composition of the melts has dramatic implications concerning the interpretation of granitic rocks, especially when using phase relationships to discuss the formation or the crystallization histories of these rocks. The $\mathrm{H}_{2} \mathrm{O}$ content of the melts is an important parameter which should be taken into account in petrogenetic investigations of granitic rocks. The results of this study, in confirming a strong composition dependence of the solubility of $\mathrm{H}_{2} \mathrm{O}$ in silicate melts, set the stage for an investigation of the effect of light elements on the solubility of $\mathrm{H}_{2} \mathrm{O}$ in leucogranitic systems (e.g., B, Li, F).

\section{Acknowledgements}

This work was partly supported by Procope (German-French research program No. 91162 between Hannover and Orléans). Technical assistance was provided by $O$. Diedrich (preparation of samples), M. Nowak and F. Schulze (realisation of experiments, Karl-Fischer titration, and drawing of figures). Thanks are due to Y. Bottinga and M. Pichavant for careful review of the manuscript.

\section{References}

Blamart, D., Graham, C.M. and Sheppard, S.M.F., 1988. The system $\mathrm{NaAlSi}_{3} \mathrm{O}_{8}$ (melt)- $\mathrm{H}_{2} \mathrm{O}$-sea water: solubility of water and hydrogen isotope fractionation factor at 3, 5 and $8 \mathrm{~Kb}$. Int. Symp. on Experimental Min- eralogy and Geochemistry, Abstr. Vol., Nancy, pp. 2324.

Burnham, C.W., 1963. Viscosity of a water-rich pegmatite. Geol. Soc. Am., Spec. Pap., 76: 26 (abstract).

Burnham, C.W., 1981. The nature of multicomponent aluminosilicate melts. Phys. Chem. Earth, 13-14: 197229.

Burnham, C.W. and Jahns, R.H., 1962. A method for determining the solubility of water in silicate melts. Am. J. Sci., 260: 721-745.

Day, H.W. and Fenn, P.M., 1982. Estimating the P-T$X \mathrm{H}_{2} \mathrm{O}$ conditions during crystallization of low calcium granites. J. Geol., 90: 485-507.

Dingwell, D.B., 1987. Melt viscosities in the system $\mathrm{NaAlSi}_{3} \mathrm{O}_{8}-\mathrm{H}_{2} \mathrm{O}-\mathrm{F}_{2} \mathrm{O}_{-1}$. In: B.O Mysen (Editor), Magmatic Processes: Physicochemical Principles. Geochem. Soc., Washington, D.C., Spec. Publ. No. 1, pp. 423-431.

Dingwell, D.B. and Webb, S.L., 1989. Structural relaxation in silicate melts and non-Newtonian rheology in igneous processes. Phys. Chem. Miner., 16: 508-516.

Dingwell, D.B. and Webb, S.L., 1990a. The temperaturedependence of water speciation in rhyolitic melts: analysis of quenchrate-dependent speciation data using relaxation theory. Eos (Trans. Am. Geophys. Union), 70: 501-502 (abstract).

Dingwell, D.B. and Webb, S.L., 1990b. Relaxation in silicate melts. Eur. J. Mineral., 2: 427-449.

Dingwell, D.B., Harris, D.M. and Scarfe, C.M., 1984. The solubility of $\mathrm{H}_{2} \mathrm{O}$ in melts in the system $\mathrm{SiO}_{2}-\mathrm{Al}_{2} \mathrm{O}_{3}-$ $\mathrm{Na}_{2} \mathrm{O}-\mathrm{K}_{2} \mathrm{O}$ at 1 to 2 kbars. J. Geol., 92: 387-395.

Friedman, I., Long, W. and Smith, R.L., 1963. Viscosity and water content of rhyolite glass. J. Geophys. Res., 68: 6523-6535.

Goranson, R.W., 1931. The solubility of water in granitic magmas. Am. J. Sci., 22: 481-502.

Hamilton, D.L. and Oxtoby, S., 1986. Solubility of water in albite melt determined by the weight-loss method. J. Geol., 94: 626-630.

Holtz, F., Pichavant, M., Barbey, P. and Johannes, W., 1992. Effects of $\mathrm{H}_{2} \mathrm{O}$ on liquidus phase relations in the haplogranite system at 2 and 5 kbar. Am. Mineral. (submitted).

Kennedy, G.C., Wasserburg, G.J., Heard, H.C. and Newton, R.C., 1962. The upper three-phase region in the system $\mathrm{SiO}_{2}-\mathrm{H}_{2}$ O. Am. J. Sci., 260: 501-521.

Khitarov, N.I., Lebedev, E.B., Rengarten, E.V. and Arsen'eva, R.V., 1959. The solubility of water in basaltic and granitic melts. Geochemistry, 5: 479-492.

Kohn, S.C., Dupree, R. and Smith, M.E., 1989. A multinuclear magnetic resonance study of the structure of hydrous albite glasses. Geochim. Cosmochim. Acta, 53: 2925-2935.

Lapham, K.E., Holloway, J.R. and Delaney, J.R., 1984. Diffusion of $\mathrm{H}_{2} \mathrm{O}$ and $\mathrm{D}_{2} \mathrm{O}$ in obsidian at elevated temperatures and pressures. J. Non-Cryst. Solids, 67: $179-191$. 
Luth, W.C., 1976. Granitic rocks. In: D.K. Bailey and R. MacDonalds (Editors), The Evolution of the Crystalline Rocks. Academic Press, London, pp. 335-417.

Luth, W.C., Jahns, R.H. and Tuttle, O.F., 1964. The granite system at pressures of 4 to 10 kilobars. J. Geophys. Res., 69: 759-773.

McMillan, P.F. and Holloway, J.R., 1987. Water solubility in aluminosilicate melts. Contrib. Mineral. Petrol., 97: 320-332.

Mysen, B.O. and Virgo, D., 1986. Volatiles in silicate melts at high pressure and temperature, 1 . Interaction between $\mathrm{OH}$ groups and $\mathrm{Si}^{4+}, \mathrm{Al}^{3+}, \mathrm{Ca}^{2+}$, and $\mathrm{H}^{+}$. Chem. Geol., 57: 303-331.

Nabelek, P.I., Russ-Nabelek, C. and Denison, J., 1992. Petrologic and geochemical constraints on the petrogenesis of the proterozoic Harney Peak leucogranite, Black Hills, South Dakota, USA. Contrib. Mineral. Petrol. (in press).

Orlova, G.P., 1963. Solubility of water in albite melts under pressure. Int. Geol. Rev., 6: 254-258.

Oxtoby, S. and Hamilton, D.L., 1978a. The discrete association of water with $\mathrm{Na}_{2} \mathrm{O}$ and $\mathrm{SiO}_{2}$ in $\mathrm{NaAl}$ silicate melts. Contrib. Mineral. Petrol., 66: 185-188.

Oxtoby, S. and Hamilton, D.L., 1978b. Calculation of the solubility of water in granitic melts. In: W.S. McKenzie (Editor), Progress in Experimental Petrology. Dep. Geol., Univ. of Manchester, Manchester, Nat. Environ. Res. Counc., Publ. Ser. D, No. 11, pp. 37-40.

Pichavant, M., 1987. Effects of $\mathrm{B}$ and $\mathrm{H}_{2} \mathrm{O}$ on liquidus phase relations in the haplogranite system at $1 \mathrm{kbar}$. Am. Mineral., 72: 1056-1071.

Pichavant, M., 1990. Phase equilibria in granitic systems: implications for $\mathrm{H}_{2} \mathrm{O}$ speciation in aluminosilicate melts. Terra Cognita, 2: 28 (abstract).
Pichavant, M., Holtz, F. and McMillan, P.F., 1992. Phase relations and compositional dependence of $\mathrm{H}_{2} \mathrm{O}$ solubility in quartz-feldspar melts. In: Y. Bottinga, D.B. Dingwell and P. Richet (Guest-Editors), Silicate Melts. Chem. Geol., 96: 303-319 (this special issue).

Silver, L.A. and Stolper, E.M., 1989. Water in albitic glasses. J. Petrol., 30: 667-710.

Silver, L.A., Ihinger, P.D. and Stolper, E.M., 1990. The influence of bulk composition on the speciation of water in silicate glasses. Contrib. Mineral. Petrol., 104: 142-162.

Stolper, E.M., 1982. Water in silicate glasses: an infrared spectroscopic study. Contrib. Mineral. Petrol., 81: 117.

Turek, A., Riddle, C., Cozens, B.J. and Tetley, N.W., 1976. Determination of chemical water in rock analysisi by Karl-Fischer titration. Chem. Geol., 17: 261-267.

Tuttle, O.F. and Bowen, N.L., 1958. Origin of granite in the light of experimental studies in the system $\mathrm{NaAl}$ $\mathrm{Si}_{3} \mathrm{O}_{8}-\mathrm{KAISi}_{3} \mathrm{O}_{8}-\mathrm{SiO}_{2}-\mathrm{H}_{2} \mathrm{O}$. Geol. Soc. Am. Mem., 74: $1-154$.

Urbain, G., Bottinga, Y. and Richet, P., 1982. Viscosity of liquid silica, silicates and aluminosilicates. Geochim. Cosmochim. Acta, 46: 1061-1072.

Voigt, D.E., Bodnar, R.J. and Blencoe, J.G., 1981. Water solubility in melts of alkali feldspar composition at 5 kbar, $950^{\circ} \mathrm{C}$. Eos (Trans. Am. Geophys. Union), 62: 428 (abstract).

Westrich, H.R., 1987. Determination of water in volcanic glasses by Karl-Fischer titration. Chem. Geol., 63: 335-340.

Zhang, Y., Stolper, E.M. and Wasserburg, G.J., 1991 . Diffusion of water in rhyolitic glasses. Geochim. Cosmochim. Acta, 55: 441 